\title{
A Positivist Study of Conversational Pragmatic Strategies
}

\author{
Senlin $\mathrm{Liu}^{1}$ \\ ${ }^{1}$ Shenzhen Tourism College of Jinan University, Shenzhen, China \\ Correspondence: Senlin Liu, Shenzhen Tourism College of Jinan University, Shenzhen, Guangdong Province, \\ China. E-mail: Liu_sl@sz.jnu.edu.cn
}

Received: May19, 2016 Accepted: June 10, 2016 Online Published: July 13, 2016

doi:10.5539/ijel.v6n4p166 URL: http://dx.doi.org/10.5539/ijel.v6n4p166

\begin{abstract}
Language use is always strategic. Speakers do not only choose linguistic forms, they also choose strategies. This paper intends to explore the ways the language users take to attain their communicate goals, i.e., pragmatic strategies. Specifically, this article aims at a comprehensive positivist of the conversational pragmatic strategies in part of the novel Man, Woman and Child by Erich Segal; the direct-indirect pragmatic strategies in the eighty-nine Coca-Cola consumer advertisements from the year 1886 up to the year 1980; the "conversational maxim" pragmatic strategies in some 793 business letters, the "conversational maxim" pragmatic strategies in seven e-mails; and the "face-management" pragmatic strategies in some 793 business letters. The goal of study is to verify the universality and feasibility of the implementation of pragmatic strategies, both in literary and business writings. Only in this way can the language users achieve their communicative goal effectively.
\end{abstract}

Keywords: pragmatic strategies, literary works, non-literary works, case studies

\section{Introduction}

This paper is intended to make a comprehensive positivist case study of the conversational pragmatic strategies in the novel Man, Woman and Child by Erich Segal (1985); the direct-indirect pragmatic strategies in the eighty-nine Coca-Cola consumer advertisements (Note 1) from the year 1886 up to the year 1980; the "conversational maxim" pragmatic strategies in seven e-mails; and the "face-management" pragmatic strategies in some 793 business letters. Our purpose of the positivist case studies is to further verify the universality and the feasibility of the pragmatic strategies in both oral and written, in both literary (Note 2) and non-literary communications.

\section{Data Collection, Research Methodology and Theoretical Frameworks}

\subsection{Data Collection}

Considering the universality of the data, this paper has collected both literary and non-literary writings, such as the novel Man, Woman and Child by Erich Segal eighty-nine Coca-Cola consumer advertisements seven business e-mails and 793 business letters, which can be representatives in certain registers or categories. The possible pragmatic strategies are the objectives of study in this essay.

\subsection{Research Methodology}

The analysis of the data in this article will be mainly based on the following two considerations: (1) Language use is always strategic. A speaker does not choose linguistic forms, but also chooses pragmatic strategies (Verschueren, 2000). Pragmatic strategies are the basis on which a speaker chooses linguistic forms; (2) the implementation of pragmatic strategies is universal phenomena in both oral interaction and written language communications, in both literary and non-literary texts (Leech \& Short, 1981, p. 302).

As for the research methodology, both quantitative and qualitative studies are be made for the non-literary writings such as the Coca-Cola consumer advertisements and the business letters, but only qualitative studies will be made for the literary works such as novels and the emails. Specifically, based mainly on Searle's (1975) direct-indirect speech act theories, this paper identifies or sort out the different forms of utterances and makes analysis of their anticipatory illocutionary points. Based on Leech's (1983) Politeness Principle, this article discusses, qualitatively, what pragmatic strategies are implemented in 6 passages of emails from Slembrouk (1998-2000). Based on Pilegaard's (1997, p. 224), this article makes a quantitative of 793 business letters with face-management strategies, both internal and external strategies. Based on Grice's Cooperative Principle, this 
paper makes a qualitative analysis into the conversational pragmatic strategies in the novel, Man, Woman and Child. The data, thus, collected are can be oral or written.

\subsection{Theoretical Frameworks}

The analysis on the pragmatic strategies in this article fall into four categories: conversational pragmatic strategies, the direct-indirect pragmatic strategies, "conversational maxim" pragmatic strategies and "face-management" pragmatic strategies. The corresponding theories are Austin's distinctions of speech acts, i.e., the distinctions of locution, illocution and perlocution (Austin, 1967). Searle (1977) categorizes five types of speech acts on the basis of illocutionary points, that is, the common forces of certain utterances, such as representatives, directives, commissives, expressives and declarations. Direct use of language is the simplest cases of meaning production process in which the speaker utters a sentence and means exactly and literally what he says. Indirect use of language is the cases in which one illocutionary act is performed indirectly by way of performing another (Searle, 1975). There are also some cases in which the direct and indirect use of language is switching. An ambivalent utterance always has more than one potential pragmatic force. Ambivalence occurs when the speaker does not make clear which of a range of related illocutionary values is intended. With pragmatic ambivalence, both the speaker and the hearer may understand that the utterance has more than one illocutionary force, and the rhetoric of speech acts often encourages ambivalence (Leech, 1977, 1980). Theories concerning the "conversational maxim" pragmatic strategies are originated from the maxims of Cooperative Principle (CP) of conversation, which proposed by Paul Grice in the year 1975.In either flouting of observing the maxims of CP; the conversational implicatures are the ways by which the pragmatic strategies are implemented. Generalized particularized as well as conventional implicatures are always under consideration when the pragmatic strategies are being analyzed (Grice, 1975). Last of all, the "face-management" pragmatic strategies are analyzed in the frameworks of "Politeness Principles" proposed by Geoffrey Leech in the year 1983. According to Leech (1983, p. 132), a language user can implement pragmatic strategies by observing or violating the maxims of Politeness Principles. This paper will make an attempt to apply the theories to the corresponding data analysis.

\section{Findings and Discussions}

\subsection{Conversational Pragmatic Strategies in Man, Woman and Child (Note 3)}

Man, Woman and Child is a novel written by Erich Segal, Professor of Yale University, U.S.A. The two characters of the novel, Robert (Bob, the husband) and Sheila (the wife), have been living together happily for eighteen years. One day, however, the husband tells his wife that he had an affair with a French woman doctor ten years ago and they have a child. Robert is asking his wife to help him out. The following is a part of the conversation between the husband $(\mathrm{H})$ and the wife $(\mathrm{W})$. We shall make an analysis of the pragmatic strategies implemented by both the husband and the wife below.

\section{H: Honey, I gotta talk to you.}

The husband implements a solidarity strategy by choosing the linguistic form "gotta" to emphasize the closeness between the speaker (husband) and the hearer (wife). The word "Honey" is an "in-group identity marker" used to show intimacy.

\section{W: Sure. Is there something wrong?}

The wife, in the first place, uses a "relevance hedge ('Sure')" to imply their close relationship and shows her respect for the husband's freedom to speak (i.e. negative politeness strategy). The wife chooses the linguistic form "something" to convey the implicature that something bad must have happened and she is wondering what it is.

\section{H: Well, sort of. Yes.}

The husband uses a Manner Hedge "well" followed by a Quantity Hedge "sort of". The Quantity hedge indicates that he hesitates to make his contribution as informative as is required for the current purpose of the talk exchange between him and his wife. She flouts the maxims of quantity and manner of the Cooperative Principle at the same time.

\section{W: Bob, something in your voice scares me. Have I done anything?}

The wife implements a solidarity/positive politeness strategy with the address form "Bob" as an "in-group identity marker". By using the address form, the wife confirms her husband's identity as a member of the family and their intimate relationship. It is noticeable that the wife leaves out the word "wrong" after the word "anything". Such a use of ellipsis or incompleteness flouts the maxim of quantity. Her flouting the maxim of 
quantity of the $\mathrm{CP}$ generates the implicature: who did something wrong - the wife or the husband? By saying have I done anything (wrong)? , the wife obeys the Tact Maxim. She tries to minimize the cost to the husband.

\section{H: No. It's me. I've done it. Sheila, remember when you were pregnant with Paula?}

The indeterminacy of the impersonal pronoun "it" does not provide enough information, thus the husband flouts the maxim of quantity. The implicature is that there is something on his mind that would be awkward to disclose.

\section{W: Yes?}

It can be assumed that the wife is speaking in a rising tone. And she invites her husband to go on with his story.

\section{H: I had to go to Europe-Montpellier-to give that paper...}

The husband obeys the maxim of relation of the Cooperative Principle as a "hinting strategy". The standard implicature here is that the husband is trying to remind her of the time for his affairs.

\section{W: And?}

In this case, the wife has to encourage the husband to continue along the direction of the talk exchange by obeying the maxim of manner ("Be orderly", or sequentiality) of the Cooperative Principle. The linguistic form "And" implicates her expectations.

\section{H: I had an affair.}

By saying so, the husband obeys the maxim of quality of the Cooperative Principle. He tells the truth in direct language.

\section{W: No. This is some terrible joke. Isn't it?}

The wife uses the word "No" as an exclamation to express her astonishment, skepticism and bewilderment. The use of the rhetorical questions, "Isn't it", shows that she cannot believe her husband words.

\section{H: No. It's true. I-I'm sorry.}

The husband uses a negative word "No" to confirm the fact. The dash implicates that there is a heavy load on the husband's mind.

\section{W: Who?}

The wife chooses the linguistic form of "who" instead of "whom is the woman that you committed adultery with?" in a rather direct manner by obeying the maxim of manner ("Be Brief") of the Cooperative Principle. The utterance conveys the implicature of her anger and anxiety.

\section{H: Nobody. Nobody special.}

The husband intentionally chooses the word "nobody". By choosing such a linguistic form, he implements an "off-record" pragmatic strategy (understatement). Generally speaking, the conventional meaning of the word "nobody" is "a person of no importance", which is just opposite in meaning to "somebody" ("an important person"). The generalized implicature is that the "woman" who had affair with him is of no importance to him now. And the wife may take it easy. The husband tries to minimize the cost to his wife by obeying the Tact Maxim of Politeness Principle.

\section{W: Who, Robert?}

The wife obeys the sub-maxim of Manner ("Be Brief") of the Cooperative Principle. She stresses her tone to emphasize her eagerness to know who her rival really is. The short question implicates her anger. More important, we must note that the wife has shifted her address form from "Bob" to "Robert". Such a shift implies that the wife's feeling is changing from intimacy to coldness.

\section{H: Her-her name was Nicole Guirin. She was a doctor.}

The dash implies that the husband hesitates before he tells his wife the woman's name. He honestly tells her about "everything", so he obeys the maxim of quality, but he flouts the maxim of quantity of the Cooperative Principle. It implies that he has the intention of being "sincere" to his wife.

\section{W: And how long did it last?}

The wife's utterance is ambivalent. Superficially, the wife wants to know the exact days of the romance; in fact, she wants to know whether the husband is still keeping the relationship with her rival or not.

\section{H: Two, three days.}

The husband gives a matter-of-fact answer to her question by observing the Maxim of Relation of the 
Cooperative Principle. He leaves out the conjunctive "or" between "Two" and "three days", implying that he intends to touch on it lightly.

\section{W: Two days or three days? I want to know.}

The wife flouts the maxim of quantity of the Cooperative Principle by repetition. However, she adds the conjunctive "or" to show that she is very serious about the matter. Her utterance "I want to know" goes on record. She is threatening the husband's face in direct language.

\section{H: Three days. Does all this matter?}

The husband gives a matter-of-fact answer to her question by obeying the maxim of quality. Obviously, the husband has lost his temper.

\section{W: Everything matters.}

By saying so, the wife is doing the FTA without any redressive strategies. She is threatening her husband's negative face. In other words, she violates the Tact Maxim of Politeness Principle by maximizing the impolite belief to the husband.

\section{H: I was waiting for the right moment.}

The husband implements a "hinting strategy" by observing the maxim of relation of the Cooperative Principle. He hints that he has been taking the wife's face into consideration and that is why he has been always trying to find the right moment to tell her the truth and asks her for forgiveness.

\section{W: And ten years later was the right moment? No doubt you thought it would be easier. On whom?}

By using the rhetorical question, her utterance is ambivalent. The implicature of her utterance is: easier on the husband or easier on the wife herself?

\section{H: I don't want to hurt you, Sheila. If it's any consolation, that's the only time.}

The husband implements a directness strategy in his utterances.

\section{W: No, it isn't any consolation. One is more than never.}

Generally, we say "more than ever". However, the well-educated wife changed it into "one is more than never". It implies that the wife never expects such a thing to have happened.

\section{H: Sheila, that was so long ago. I had to tell you now because - I mean...She's dead.}

By stating the facts that (1) the love affair took place long ago, and (2) that the French woman doctor is dead, the husband tries to implicate that he has nothing to do with the woman now. The husband obeys the maxim of quality of the Cooperative Principle.

\section{W: For God's sake. Bob, why are you telling me all this?}

The wife implements a solidarity pragmatic strategy to implicate her love for her husband by reusing the intimate address form "Bob". By saying "why are you telling me all this", the wife implements an ambivalent pragmatic strategy. On the surface, it seems that she is asking a question; in fact, her utterance implies her forgiveness for the husband.

\section{H: Sheila, I am telling you because she had a child.}

The husband calls her wife "Sheila" to express the intimacy by implementing a solidarity pragmatic strategy. However, he suddenly changes the topic of the conversation. This time, the wife is not aware of such a change. She thought that the indefinite article "a" is a generalized conversational implicature that the boy is not her husband's. In fact, the indefinite article "a" is used as a particularized conversational implicature in this circumstance. Thus, the generalized implicature has been cancelled. Instead, a particularized implicature is generated, i.e., the boy is his.

\section{W: And we have two-so what?}

The wife mistook the husband, owing to her misunderstanding the implicature of the indefinite article.

\section{H: He's mine. The boy is mine.}

The husband emphasizes the seriousness of the matter by repetition. He flouts the maxim of quantity of the CP.

\section{W: Oh, no, it can't be true.}

The wife flouts the maxim of quality, for she is saying something untrue. 


\section{H: Yes, it's true. I didn't know about him. Sheila, Please believe me.}

By observing the maxim of quality, the husband is trying to regain his credibility from his wife.

\section{W: Why? Why should I believe anything you tell me now?}

The wife uses a repetition (why?) and a rhetorical question to imply that she will never believe her husband. She feels that he has fooled her around twice. The fact is unacceptable to her.

\section{H: Sheila, listen...}

\section{W: No. I've heard enough.}

In the adjacency pair above, the husband intends to make a request. However, the wife rejects his request.

\section{W: Bob, why'd you have to tell me? Why?}

It must be noted that the wife still uses the intimate address form "Bob" instead of "Robert". Her solidarity pragmatic strategy reflects the conflict in her mind.

\section{H: Because I don't know what to do. And because I somehow thought you'd help.}

The husband implements a direct strategy.

\section{W: You can't know how it hurts. I trusted you. I trusted you.}

The wife flouts the maxim of quantity by repetition, which implicates her disappointment and anger.

\section{H: Please, honey. I'll do anything to make it right.}

The husband tries to comfort his wife by using the in-group identity marker "honey" to seek for their common ground. By choosing the word "anything", the husband implements an off record strategy in the overstatement or hyperbole. His utterances imply that he is determined to find a solution to the problem.

\section{W: You can't.}

The wife's utterance might be pluravalent. On the one hand, her utterances mean that the husband does not have any ability to change the reality of the existence of the child; on the other hand, it might mean that it is impossible for the husband to change her disappointment at the facts.

H:...

In a word, evidence is piling up that the wife and husband implements the pragmatic strategies, such as either obeying or flouting the maxims of the $\mathrm{CP}$, either obeying or flouting the maxims of the PP, either directness or indirectness, and the face-saving speech acts.

\subsection{Direct-indirect Pragmatic Strategies in Coca-Cola Consumer Advertisements (Note 4)}

\subsubsection{Coca-Cola Consumer Advertisement and Directive Speech Act}

By consumer advertisements, we mean those advertisements that are aimed at the individuals or ultimate consumers who purchase the products for personal reasons or non-business reasons (Bovée \& Arens, 1982). The anticipatory illocutionary point of the Coca-Cola consumer advertisements is to get the consumers to buy the Coca-Cola products. The prototypical use (characteristic use) of the Coca-Cola advertisements is directive.

Our discussion will be based on the theory of direct-indirect pragmatic strategies.

Our research methodology will be both quantitative and qualitative.

Our discussion will be based on the assumption that the Coca-Cola advertisement is "truth well told". That is to say, the adman, at least, obeys the maxim of Quality of the Cooperative Principle. It involves convincing people that the Coca-Cola products will benefit them.

\subsubsection{Direct-indirect Pragmatic Strategies in Coca-Cola Consumer Advertisements}

Altogether, we have collected eighty-nine items of the Coca-Cola advertisements from the year 1886 up to the year 1980. Based on Searle's classification of speech acts, we shall divide the pragmatic strategies in the Coca-Cola advertisements into three categories: direct strategy, indirect strategy and ambivalent strategy. The reference point of the direct-indirect strategy of the Coca-Cola advertisements is its characteristic use of prototypical directive. In Table 1, if a speech in an advertisement performs a directive function, it is considered a direct pragmatic strategy. If an advertisement performs the directive function by either a representative, or an expressive, or a commissive, or a declarative, it will be defined as an indirect pragmatic strategy. If an utterance has several possible illocutionary forces, the utterance is considered pragmatically ambivalent. 
We shall make a quantitative analysis and a qualitative description after a statistical survey of the data.

Table 1. Categories of speech acts in Coca-Cola

\begin{tabular}{|c|c|c|c|c|}
\hline Advertisements & $\begin{array}{l}\text { Actual Speech } \\
\text { Act Type }\end{array}$ & $\begin{array}{l}\text { Direct } \\
\text { Strategy } \\
\end{array}$ & $\begin{array}{l}\text { Indirect } \\
\text { Strategy }\end{array}$ & Ambivalence \\
\hline 1886 Drink Coca-Cola & directive & direct & & \\
\hline 1904 Delicious and refreshing & $\begin{array}{l}\text { representative } \\
\text { expressive }\end{array}$ & & indirect & ambivalent \\
\hline 1904 Coca-Cola....satisfies & $\begin{array}{l}\text { expressive } \\
\text { representative }\end{array}$ & & indirect & ambivalent \\
\hline 1905 Coca-Cola revives and sustains & $\begin{array}{l}\text { representative } \\
\text { expressive }\end{array}$ & & indirect & ambivalent \\
\hline 1905 Wherever you go... you will find Coca-Cola. & representative & & indirect & \\
\hline 1906 The drink of quality & representative & & indirect & \\
\hline 1906 The great national temperance beverage & $\begin{array}{l}\text { representative } \\
\text { expressive }\end{array}$ & & indirect & Ambivalent \\
\hline $\begin{array}{l}1907 \text { Coca-Cola is full of vim, vigor and go- is a snappy } \\
\text { drink. }\end{array}$ & representative & & indirect & \\
\hline 1908 Get the genuine & directive & direct & & \\
\hline 1909 Wherever you see an arrow, think of Coca-Cola. & representative & & indirect & \\
\hline 1911 Enjoy a glass of liquid laughter & directive & direct & & \\
\hline 1917 Three million a day & representative & & indirect & \\
\hline $\begin{array}{l}1920 \text { Coca-Cola...good things from } 9 \text { climes poured into a } \\
\text { single glass }\end{array}$ & representative & & indirect & \\
\hline 1922 Thirst knows no reason. & representative & & indirect & \\
\hline 1923 Enjoy thirst & directive & direct & & \\
\hline 1925 It has the charm of purity. & representative & & indirect & \\
\hline 1925 With a drink so good...'tis folly to be thirst & expressive & & indirect & \\
\hline 1925 Six Million a day & representative & & indirect & \\
\hline $\begin{array}{l}1926 \text { Coca-Cola is the shortest distance between thirst and } \\
\text { refreshment. }\end{array}$ & representative & & indirect & \\
\hline 1927 It had to be good to get where it is. & representative & & indirect & \\
\hline 1927 Around the corner from anywhere & representative & & indirect & \\
\hline 1927 At the little red sign & representative & & indirect & \\
\hline 1928 Coca-Cola.... a pure drink of natural flavours & representative & & indirect & \\
\hline 1929 The best served drink in the world & representative & & indirect & \\
\hline 1929 The pause that refreshes & expressive & & indirect & \\
\hline 1932 Ice-cold sunshine & expressive & & indirect & \\
\hline 1932 Thirst come, thirst served & representative & & indirect & \\
\hline 1933 Bounce back to normal & representative & & indirect & \\
\hline 1933 Don't wear a tired, thirsty face & directive & direct & & \\
\hline 1935 Coca-Cola...the pause that brings friends together & representative & & indirect & \\
\hline 1937 America's favorite moment & $\begin{array}{l}\text { representative } \\
\text { expressive }\end{array}$ & & indirect & ambivalent \\
\hline 1938 The best friend thirst ever had & representative & & indirect & \\
\hline 1939 Coca-Cola goes along & representative & & indirect & \\
\hline 1939 Coca-Cola has the taste thirst goes for. & representative & & indirect & \\
\hline $\begin{array}{l}1939 \text { Whoever you are, whatever you do, wherever you may } \\
\text { be, when you think of refreshment, think of ice-cold } \\
\text { Coca-Cola. }\end{array}$ & representative & & indirect & \\
\hline 1940 Within easy reach of your thirst & representative & & indirect & \\
\hline 1940 America's year around answer to thirst & $\begin{array}{l}\text { representative } \\
\text { expressive }\end{array}$ & & indirect & ambivalent \\
\hline 1941 Work refreshed & $\begin{array}{l}\text { representative } \\
\text { expressive }\end{array}$ & & indirect & ambivalent \\
\hline 1941 Coca-Cola belongs... & representative & & indirect & \\
\hline 1942 The only thing like Coca-Cola is Coca-Cola itself. & representative & & indirect & \\
\hline 1942 Coca-Cola has that extra something. & representative & & indirect & \\
\hline 1942 The best is always the better buy. & representative & & indirect & \\
\hline 1942 It's the real thing. & $\begin{array}{l}\text { representative } \\
\text { expressive }\end{array}$ & & indirect & ambivalent \\
\hline $\begin{array}{l}1943 \text { Universal symbol of the American way of } \\
\text { life...Coca-Cola }\end{array}$ & Representative & & indirect & \\
\hline 1943 With a taste of its own & representative & & indirect & \\
\hline
\end{tabular}


1945 The happy symbol of a friendly way of life 1945 Why grow thirsty?

1946 The world's friendliest club...admission 5 cents 1946 Yes

1947 Continuous quality is quality you trust. 1947 The quality of Coca-Cola is a friendly quality you can always trust.

1948 Where there is Coca-Cola, there is hospitality.

1949 Coca-Cola... along the high way to anywhere

1950 Thirst, too, seeks quality.

1951 For home and hospitality

1951 You taste its quality.

1952 What you want is a Coke.

1952 Coke follows thirst everywhere.

1953 Drive safely...Drive refreshed

1953 Midsummer Magic

1955 Bright and Bracing as sunshine

1956 Coca-Cola...makes good things taste better.

1956 The friendliest drink on earth

1956 Gives a bright little gift

1956 Coca-Cola puts you at your sparkling best.

1957 Sign of good taste

1958 The cold, crisp taste of Coke

1959 Cheerful life of Coke

1959 Relax refreshed with ice-cold Coca-Cola 1959 Be really refreshed

1959 The cold, crisp taste that so deeply satisfies

1961 Coca-Cola refreshes you best.

1963 The big bold taste that's always just right

1963 Things go better with Coke.

1963 Go better refreshed

1964 Coca-Cola gives that special zing...refreshes best.

1965 Enjoy Coca-Cola

1965 For extra fun-take more than one! Take an extra carton

of Coke!

1966 Coca-Cola has the taste you never get rid of.

1968 Tells your thirst to go fly a kite

1968 Wave after wave-drink after drink

1968 For twice the convenience, bring home two cartons of

Coke

1968 It's twice time.

1970 It's the real thing.

1971 I'd like to buy the world a Coke.

1972 Coke...goes with the good times

1975 Look up America, see what we've got

1976 Coke adds life...

1980 Have a Coke and a smile

Total 89

Percentage representative

representative

representative

representative

expressive

representative

representative

representative

representative

representative

expressive

directive

representative

representative

directive

representative

expressive

expressive

representative

representative

expressive

directive

representative

representative

representative

expressive

representative

expressive

representative

expressive

representative

representative

expressive

representative

representative

representative

Expressive

representative

representative

directive

directive

representative

expressive

expressive

directive

directive

expressive

representative

representative

expressive

commissive

expressive

representative

expressive

directive

expressive

expressive

representative

directive indirect

indirect

indirect

indirect

ambivalent

indirect

indirect

indirect

indirect

indirect

indirect

direct

indirect

indirect

indirect

ambivalent

indirect

indirect

indirect

indirect

ambivalent

direct

indirect

indirect

indirect

ambivalent

indirect

ambivalent

indirect

indirect

ambivalent

indirect

ambivalent

indirect

indirect

indirect

indirect

ambivalent

indirect

direct

direct

indirect

indirect

indirect

direct

indirect ambivalent

indirect ambivalent

indirect ambivalent

indirect ambivalent

indirect

indirect ambivalent

direct

$\begin{array}{lll}11 & 78 & 21\end{array}$

$12.3 \% \quad 87.7 \% \quad 26 \%$


Table 1 shows that out of the eighty-nine Coca-Cola consumer advertisements, there are only ten direct pragmatic strategies ( $12.7 \%$ of the total). However, there are seventy-nine indirect pragmatic strategies $(87.7 \%$ of the total). Of the seventy-nine indirect strategies, there are, at least, twenty-one ambivalent ( $26 \%$ of the indirect strategies) strategies. The figures bring out the fact that deliberate indirectness is a frequently implemented pragmatic strategy in consumer advertisements.

It is likely that the adman implements the indirect pragmatic strategies in the consumer advertisements for the following reasons:

(1) He desires to make his language more interesting. For example, saying "ice-cold sunshine" is more interesting than saying "drinks" in a direct or a plain way.

(2) He intends to increase the force of his message. Saying "Wherever you go, you'll find Coca-Cola" is more powerful than saying "Buy a Coke in your region".

(3) He tries to find a solution to the competing goals between his promoting the products and saving the communicators' face for politeness reasons. In some cultures, like the traditional Chinese culture, bargaining or talking about money is considered a shame. The Coca-Cola adman implements the pragmatic strategy of indirectness to give more options to the consumers. In such a way, the conflicts between his goal of promotion and that of the face-saving can be mitigated or balanced.

\section{3 "Conversational Maxim” Pragmatic Strategies in Emails}

In this section, we shall discuss how the politeness strategies based on the maxims of Politeness Principle of Leech are implemented in the following emails. The following emails from Yahoo (Slembrouk, 1998-2000) are taken as our data. Let us have a look at the data and make an analysis of the "conversational maxim" politeness strategies in the following emails:

Data 1. Tact Maxim (in impositives and commissives)

From: $<\ldots>$

To: $<\ldots>$

Subject:...

Send reply to: ...

Date sent: ...

Hi [first name], How is Jane?...

This message is partly on behalf of [first name+surname](from [name] University), whose organizing a Research Seminar in... which is to take place in September (26-27). He would like to invite you as a discussant for a round table multimedia translation research (translation studies finally discovering the need for discourse analysis!).

Let me give you a bit more background. [first name] is the coordinator for the inter-university programme on translation studies here. It involves Gent Univ. and couple of higher institutes for translation and interpretation. I run a course in the programme on processes of translation and editing in the media-essentially dealing with phenomena of discourse representation. I think that [first name] is gradually getting convinced of the need for a reflexive, critical type of discourse analysis within translation studies (which, at the moment, is almost entirely geared towards practical problem-solving models). As I see it, this could entail more than introducing a discourse perspective; there is also an important inroad from the study of the globalization of discursive practices, for instance, translation practices as "intertextuality", which may be constructive for the development of domain-related genres in different "national" contexts. Etc. Etc.

Anyway. Would you be interested in contributing to this event? Travel and expenses will be paid for and, if you wish, you also give a plenary paper.

If you like, you can contact[initial+surname] directly. His e-mail address is [account]@[name].ac.be

Take care! (I look forward to seeing you in Aston)

By for now,

[first name].

PS: I'll put a copy of the brochure in the post today. 
Analysis of Data 1: The email writer is "other-oriented" in the generation of the whole letter of data 1 . That is to say, s/he is always considering benefiting the reader. All the contents of the email in italics can prove my argument. A case in point is the italicized part of Travel and expenses will be paid for and, if you could also give a plenary paper. In this utterance, the email writer takes the size of imposition into consideration. That is why he makes an effort to mitigate the effect of his requesting a plenary paper by offering optionality on the cost/benefit scale (i.e. the use of the verb "could") to try to reach his goal of "inviting" the requestee and "request" a plenary paper from the requestee. However, the email writer never mentioned the benefit of his own. Thus, the email writer obeys the Tact Maxim: "minimize cost to other, maximize benefit to other".

Data 2. Generosity Maxim (in impositives and commissves)

From: [first name+surname] $<[$ account $@ \ldots$...ac.uk $]>$

To:[first name+surname] $<[$ account $] @ \ldots . .$. ac.be $>$

Subject: Re:...

Date sent:...

Priority: Normal

Hi [first name]

Sorry for not responding so far, I have in fact read through the paper and have made all sorts of comments. The drag is to insert these in the file, which I was hoping to do this morning. The ideal thing would be to do a telnent chat, if it were to be possible. But since you are at home, I'll do the insertion and send you the file before leaving for home. That's a promise. The keyboard feels strange after the break...We had a wonderful time in Devon. We stayed in a village called Mortonhamstead and from there took short excursions to Torquary, Paignton, Plymouth etc. [name child] enjoyed the day with the ponies. And the weather was simply brilliant. So, you can imagine the disorientation on the first day back at work. Also, I had to sort out my travel arrangements this morning - only two more working days to go!

How are you all? Hope you had good break too.

Best.

[First name]

Analysis of Data 2: The italicized parts of Data 2 show us how the Generosity Strategy is being implemented. That is to say, the email writer promises to get the things ready for the hearer. In this way, the writer's utterances sound generous to the reader and beneficial to the reader.

Data 3. Approbation Maxim (in expressives and assertives)

Date sent: ...

From:...

To:...

Subject: Re:...

Hi [first name],

Good to hear from you. I've just had a quick look at your webpages.

Looks good!!

.......

Bye for now,

[first name],

Analysis of Data 3: The Approbation Maxim reads, "Minimize dispraise of other, maximize praise of other". The email writer of Data 3 obeys this maxim as his pragmatic strategy in the italicized part "Looks good" to "maximize the praise of other (reader)". 
Data 4. Modesty Maxim (in expressives and assertives)

Date:...

From:...[first name+surname $]<[$ account $] @$...CompuService.com $>$

To: [first name] $<$ account]@...ac.be $>$

Subject: Books arrive

Hi [first name]

It seems to have taken an age to get here in the post from Belgium-even though it's all down hills from you to us-but it's finally arrived. Many thanks for the dedication! I feel quite envious of you leaving a - hardback-book!

I'm rushing around getting ready for Mexico-off on Thursday, but email as usual.

Love to all the young'uns, and the missus.

[initial]

Analysis of Data 4: The Modesty Maxim states: Minimize the expression of praise of self, maximize the expression of dispraise of self. By saying "I feel quite envious of you having a hardback book!", the email writer of Data 4 makes a compliment of the reader. The writer maximizes the praise of the reader, but minimizes the dispraise of self.

Data 5. Agreement maxim (in assertives)

From: [account]@waikato.ac.nz

Date sent:...

Subject: Re:....article

To: [account]@....ac.be

Dear [first name]:

Thank you very much indeed for your comments. You are quite right about ideologies of work and accumulation in the capitalist system. I wish you had read the first draft!

What kind of work do you do?

Cheers,

[first name+surname]

Dear [first name+surname],

Just a brief message to let you know that I very much enjoyed reading your recent article in D\&S.

I particularly liked the discussion of agency!

One minor comment: perhaps you also have explored some of the links between the discourses of welfare and ideologies of work and accumulation in the capitalist system.

With kind regards,

[first name+surname]

Analysis of Data 5: The Agreement Maxim states, "Minimize disagreement between self and other; maximize agreement between self and other". By saying You are quite right about...or I particularly liked the discussion of agency!..., the email writer of Data 5 maximizes the agreement between self and other. By saying "Our minor comment:...", the email writer minimizes the disagreement between self and other. Thus, the email writer obeys the Agreement Maxim of the Politeness Principle. 
Data 6. Sympathy Maxim (in assertives)

Date sent: Tue, 20, Oct 1998 14:19:37+1100

To: [first name+surname] $<$ [user name]@rug.ac.be $>$

From:[first name+surname $<$ [account]@deakin.edu.au $>$ ]

Subject: Re: **SS-referee report**

Thanks [first name], would be interested in the second conference on your list, hope you are well, busy as hell like all of us of course!!! All the best, and thanks for the report, report, regards, [first name]

Analysis of Data 6: By saying "busy as hell as all of us!!!", the email writer maximizes sympathy towards the reader by obeying the Sympathy Maxim of the Politeness Principle: Maximize sympathy towards the hearer, minimize antipathy towards the hearer.

\section{4 "Face-management" Politeness Pragmatic Strategies in Business Letters}

In this section, we shall make a positivist study, both quantitative and qualitative, of the universality and feasibility of the face-management strategies in business letters.

Our study is based on Pilegaard's (1997, p. 224) investigation into the principles and practices of the face-management politeness strategies in the generation of business communications. The research is based on a corpus of 793 English business letters (1979-1991) collected by Cambridge University in 1997, England, and analyzed at the Aarhus School of Business, Denmark. The following tables 3-5 show how politeness strategies, both positive and negative, are distributed and implemented in business letters. In these tables, the strategies in the propositional sections are termed "internal" strategies, while the strategies in the opening and closing sections of the business letters are termed "external" strategies.

Table 2. Politeness and text category

\begin{tabular}{llll}
\hline Text Types & Positive strategies & Negative strategies & Total \\
\hline Making contact (establish relationship) & $46.5 \%$ & $53.5 \%$ & $100 \%$ \\
Negotiating (order) & $41.2 \%$ & $58.8 \%$ & $100 \%$ \\
In conflict (positiveness vs. negativeness) & $25.6 \%$ & $74.4 \%$ & $100 \%$ \\
\hline
\end{tabular}

Table 2 shows that there is a fairly even distribution of negative $(53.5 \%)$ and positive $(46.5 \%)$ in the letters aimed at "making contact". At the stage of "negotiating", the percentage of negative (58.8\%) strategies is higher than positive (41.2\%) strategies. In letters where the two sides of the negotiation are "in conflict", negative strategies amount to $74.4 \%$; however, the positive strategies only take up $25.6 \%$. To conclude, the relative importance of negative politeness strategies are on the increase with the development of the business and the change of the relevant relationship between sellers and the buyers.

Table 3. Politeness and letter type

\begin{tabular}{llll}
\hline Letter type & Positive strategies & Negative strategies & Total \\
\hline Sales letters & $57.6 \%$ & $42.4 \%$ & $100 \%$ \\
Inquiries & $26.2 \%$ & $73.8 \%$ & $100 \%$ \\
Quotations & $47.5 \%$ & $52.5 \%$ & $100 \%$ \\
Orders & $20.5 \%$ & $79.5 \%$ & $100 \%$ \\
Reminders & $22.7 \%$ & $77.3 \%$ & $100 \%$ \\
Complaints & $22.0 \%$ & $78.0 \%$ & $100 \%$ \\
\hline
\end{tabular}

In Table 3, we can see that the salesmen implements more positive strategies (57.6\% in Sales letters) than negative strategies $(42.4 \%)$. However, the buyers (inquirers) implements less positive strategies $(26.2 \%$ in Inquiries) than negative strategies (73.8\%). In other words, the salesmen implements more positive strategies $(57.6 \%)$ than the inquirers $(26.2 \%)$. The salesmen implements less negative strategies $(42.2 \%)$, but the buyers (inquirers) implements more negative strategies (73.2\%). The same thing happens to the relationship between quotations and orders $(47.5 \%$ vs. $20.5 \%$ in positive strategies and $52 \%$ vs. $73.8 \%$ in negative strategies). Still, the same thing happens to the relationship between reminders and complaints (positive strategies $22.7 \%$ vs. $22 \%$; 
negative strategies $77.3 \%$ vs. $78 \%$ ). Therefore, the politeness strategies are closely related to the need for face redress and relative weight of imposition in business letters.

Table 4. Text-position of positive and negative politeness

\begin{tabular}{llllllll}
\hline \multirow{2}{*}{ Category } & Letter type & \multicolumn{3}{l}{ Positive politeness strategies } & \multicolumn{3}{c}{ Negative politeness strategies } \\
\cline { 2 - 7 } & & External & internal & Total & External & Internal & Total \\
\hline Making & Sales letters & $72.9 \%$ & $27.1 \%$ & $100 \%$ & $28.0 \%$ & $72.0 \%$ & $100 \%$ \\
contact & Inquires & $86.2 \%$ & $13.8 \%$ & $100 \%$ & $33.8 \%$ & $66.2 \%$ & $100 \%$ \\
& Other letters & $97.7 \%$ & $2.3 \%$ & $100 \%$ & $53.0 \%$ & $47.0 \%$ & $100 \%$ \\
\multirow{3}{*}{ Negotiating } & Quotations & $56.5 \%$ & $43.5 \%$ & $100 \%$ & $58.3 \%$ & $41.7 \%$ & $100 \%$ \\
& Orders & $37.5 \%$ & $62.5 \%$ & $100 \%$ & $3.2 \%$ & $96.8 \%$ & $100 \%$ \\
& Other letters & $51.5 \%$ & $48.5 \%$ & $100 \%$ & $14.0 \%$ & $76.3 \%$ & $100 \%$ \\
& Reminders & $28.0 \%$ & $72.0 \%$ & $100 \%$ & $3.2 \%$ & $96.8 \%$ & $100 \%$ \\
& Complaints & $39.4 \%$ & $60.6 \%$ & $100 \%$ & $24.1 \%$ & $75.9 \%$ & $100 \%$ \\
& Other letters & $23.7 \%$ & $76.3 \%$ & $100 \%$ & $40.9 \%$ & $59.1 \%$ & $100 \%$ \\
\hline
\end{tabular}

Table 4 shows the distribution of the positive and negative strategies in the external and internal positions in different types of business letters at the three different stages (i.e., making contact, negotiating and in conflict) of business communications. At the "making contact" stage, $72.9 \%$ of positive politeness strategies are in the external positions, but $27.1 \%$ of the positive politeness strategies are in the internal positions of the sales letters. $28.0 \%$ of the negative politeness strategies are in the external positions, but $72 \%$ of the negative politeness is in the internal positions of sales letters. At the "negotiating" stage, the salesman implements nearly as many external strategies as internal ones. When the two sides are "in conflict", less positive strategies are implemented in the external positions, more positive strategies are implemented in the internal positions. As to the negative strategies in the "in conflict" situation, more internal strategies are implemented than the external strategies. The same analysis can be made to other types of business letters at the three different stages. To sum up, the figure shows that the salesmen tend to implement more positive strategies (or less negative strategies) at the "making contact" stage. Nearly an equal number of the external and internal politeness strategies are implemented at the negotiating stage. When the communicators are "in conflict", they tend to implement more positive and negative politeness strategies in the internal positions. In other words, the communicators tend to implement less positive and negative strategies in the external positions.

Table 5. Text-position of politeness category

\begin{tabular}{|c|c|c|c|c|c|c|c|c|c|c|c|c|c|}
\hline \multirow[t]{3}{*}{ Category } & \multirow{3}{*}{$\begin{array}{l}\text { Letter } \\
\text { type }\end{array}$} & \multicolumn{6}{|c|}{ Positive politeness categories } & \multicolumn{6}{|c|}{ Negative politeness categories } \\
\hline & & \multicolumn{2}{|c|}{$\begin{array}{l}\text { Claim common } \\
\text { ground }\end{array}$} & \multicolumn{2}{|c|}{$\begin{array}{l}\text { Focus on } \\
\text { cooperation }\end{array}$} & \multicolumn{2}{|c|}{$\begin{array}{l}\text { Fulfill R's } \\
\text { wants }\end{array}$} & \multicolumn{2}{|c|}{$\begin{array}{l}\text { Give freedom } \\
\text { of action }\end{array}$} & \multicolumn{2}{|c|}{$\begin{array}{l}\text { Minimize } \\
\text { imposition }\end{array}$} & \multicolumn{2}{|c|}{$\begin{array}{l}\text { Dissociate } S / R \\
\text { from act }\end{array}$} \\
\hline & & Ext & Int & Ext & Int & Ext & Int & Ext & Int & Ext & Int & Ext & Int \\
\hline \multirow{3}{*}{$\begin{array}{l}\text { Making } \\
\text { contact }\end{array}$} & SAL & 41.9 & 8.7 & 50.0 & 86.9 & 8.1 & 4.4 & 57.1 & 34.1 & 20.0 & 25.3 & 22.8 & 40.6 \\
\hline & INQ & 33.9 & 11.1 & 58.9 & 88.9 & 8.2 & 0.0 & 42.0 & 47.2 & 22.5 & 16.5 & 35.5 & 36.3 \\
\hline & OTL & 47.6 & 25.0 & 50.5 & 1.9 & 50.0 & 1.9 & 25.0 & 44.7 & 23.2 & 21.0 & 47.6 & 34.3 \\
\hline \multirow[t]{3}{*}{ Negotiating } & QUO & 44.6 & 47.0 & 52.5 & 49.3 & 2.9 & 3.7 & 32.1 & 28.6 & 22.4 & 27.8 & 45.5 & 43.6 \\
\hline & ORD & 33.3 & 20.0 & 66.7 & 80.0 & 0.0 & 0.0 & 100 & 23.3 & 0.0 & 100 & 0.0 & 6.7 \\
\hline & OTL & 50.8 & 30.2 & 12.8 & 67.9 & 6.4 & 1.9 & 26.5 & 38.9 & 32.3 & 27.9 & 41.2 & 33.2 \\
\hline \multirow[t]{3}{*}{ In conflict } & REM & 60.0 & 15.4 & 40.0 & 89.6 & 0.0 & 0.0 & 50.0 & 30.7 & 0.0 & 14.5 & 50.0 & 54.8 \\
\hline & $\mathrm{COM}$ & 25.0 & 50.0 & 75.0 & 50.0 & 0.0 & 0.0 & 7.0 & 25.0 & 42.9 & 27.3 & 50.1 & 47.7 \\
\hline & OTL & 57.1 & 51.7 & 42.9 & 48.8 & 0.0 & 3.5 & 34.4 & 29.6 & 21.9 & 19.8 & 43.7 & 51.5 \\
\hline
\end{tabular}

Figures are given in percentage. Abbreviation: SAL sales letter, INQ Inquiries, OTL other letters, QUO quotation letters, ORD order, REM reminder, COM complaint, Ext external position, Int internal position.

In Table 5, we can see how the specific positive and negative strategies are distributed in external and internal positions in each letter type at the three different stages of business communications. Table 5 makes it possible for us to compare and contrast the text-sequential percentage distribution of the specific politeness categories. Generally speaking, positive strategies serve solidarity aspects of face, thus they are dominant in the external position except in "orders" and "in conflicts". The negative strategies appear in the places where "requests" are made, for example, in "making contact" and "quotations". For example, $72.9 \%$ of the positive strategies are 
found in the external position in the sales letters of the corpus, but $27.1 \%$ are found in the "request" sentences in the internal/propositional section of a letter etc. In the external positions of the business letters, sellers "claim common ground" (sales letters $41.9 \%$, quotations $44.6 \%$, reminders $60.0 \%$ ) more frequently than the buyers (inquiries $33.9 \%$, orders $33.3 \%$, complaints $25.0 \%$ ). Conversely, buyers implement more strategies of "focus on cooperation" (inquiries $33.9 \%$, orders $66.7 \%$, complaints $75 \%$ ) than the sellers (sales letters $50.0 \%$, quotations $52.5 \%$, reminders $40.0 \%$ ). The strategy "fulfill Receiver's wants" is seldom seen in the openings and closings in all types of letters. Concerning the negative politeness strategy, sellers tend to give more freedom to the receivers in the external sections (sales letters $57.1 \%$, reminders $50.0 \%$ ) than buyers (inquiries $42 \%$, complaints $7 \%$ ). In the requesting sentences, sellers tend to "dissociate" themselves or the receiver more "from the act" (sales letters $40.6 \%$, quotations $43.6 \%$, reminders $54.8 \%$ ) than buyers (inquiries $36.3 \%$, orders $6.7 \%$, complaints $47.7 \%$ ). The analysis above shows that the implementation of the face-management politeness strategies is widely distributed in business letters.

All reliable data above justify the following conclusions:

(1) Politeness phenomenon is universal in business letters;

(2) The "Conversational maxim" Politeness strategies are feasible in business texts;

(3) The main factors that influence the speakers' choice of politeness strategies are: the relative power of the speaker over the hearer; the social distance between the speaker and the hearer; the degree of imposition; and the relative rights and obligations between the speaker and the hearer.

The following example taken from the Cambridge corpus provided by Pilegaard (1997) illustrates how the politeness strategies are encoded and how they operate at the text level.

Dear...

Further to our $^{(1)}$ telephone conversation today I finally managed to speak to your colleagues in Cheltenham who assured me that, with a suitable switch the Desk Top Publishing Package can be configured as a liking machine and that, with Microsoft word, can also search and replace ASCII coding.

Accordingly, and on this basis, please ${ }^{(2)}$ regard this letter as our official order for one Desk Top Publishing Package, at $£ 7,495$, excluding VAT. Perhaps ${ }^{3}$ you will let me have your invoice so that ${ }^{(4)}$ we may ${ }^{(5)}$ complete the necessary paperwork. At the same time please $\left.{ }^{(}\right)$indicate delivery availability ${ }^{(7)}$ Could $^{(8)}$ you also note that the upgrade software, version 1.2, should $^{9}$ be supplied ${ }^{10}$.

Yours sincerely,

This letter belongs to the type of business "order". The opening section of the letter contains a salutation (Dear), which does not contain any face-management politeness strategy. The opening section has only one positive politeness strategy, i.e., "focus on cooperation" (1): our), which is external. The second paragraph contains negative strategies. The receiver's "freedom of action" is stressed by "conventional indirectness", which is "receiver-oriented" (8): could you; (9): should) and in one case sender-based (5): To "minimize the imposition", the sender resorts to the conventional politeness marker please (2), (6)). "Dissociation from the face-threatening act" is achieved by stating the reason for doing the FTA (4): so) and by impersonalising sender and receiver with nominalization (7): delivery availability) and passive construction (10: Be supplied).

\section{Conclusion}

Our quantitative and qualitative case studies of the conversational strategies in the novel Man, Woman and Child, the direct-indirect strategies in the consumer Coca-Cola advertisement, conversational maxim politeness strategies in the emails, and the face-management pragmatic strategies in business letters on the basis of Cambridge database, all prove that the conversational pragmatic strategies are feasible for both oral and written, literary and non-literary communications.

\section{References}

Austin, J. L. (1962). How to Do Things with Words. Oxford: Clarendon Press.

Bialystock, E. (1990). Communication Strategies. Oxford: Basil Blackwell.

Blum-Kulka, S. (1987). Indirectness and politeness in request: same or different? Journal of Pragmatics, 11, 131-146. http://dx.doi.org/10.1016/0378-2166(87)90192-5

Bovée, C. L., \& Arens, W. F. (1982). Contemporary Advertising. Homewood, Illinois: Richard D. Irwin, Inc.

Brown, P., \& Levinson, S. C. (1978). Universals in language usage: politeness phenomena. In E. Goody (Ed.), 
Questions and Politeness: strategies in social Interaction (pp. 56-289). Cambridge: Cambridge University Press.

Brown, P., \& Levinson, S. C. (1987). Politeness: Some universals in language usage. Cambridge: Cambridge University Press.

Carston, R. (1991). Implicature, Explicature, and Truth-Theoretical Semantics. In S. Davis (Ed.), Pragmatics: A Reader. London: OUP.

Clark, H. H. (1991). Responding to Indirect Speech Acts. In S. Davis (Ed.), Pragmatics: A Reader. London: OUP.

Dascal, M. (2003). Interpretation and Understanding. Amsterdam: John Benjamins Publishing Company. http://dx.doi.org/10.1075/z.120

Davis, S. D. (1991). Pragmatics: A Reader. New York: Oxford University Press.

Faerch, C., \& Kasper, G. (1984). Two ways of defining communication strategies. Language Learning, 134, 45-63. http://dx.doi.org/10.1111/j.1467-1770.1984.tb00995.x

Faerch, C., \& Kasper, K. (Eds.). (1983). Strategies in Interlanguage Communication. London: Longman.

Gazdar, G. (1979). Pragmatics: Implicature, Presupposition, and Logical Form. New York: Academic Press.

Green, G. (1989). Pragmatics and Natural Language Understanding. Hillsdale, NJ: LEA Publishers.

Grundy, P. (1995). Doing Pragmatics. London: Edward Arnold.

Gumperz, J. G. (1982). Discourse Strategies. Cambridge: Cambridge University Press. http://dx.doi.org/10.1017/CBO9780511611834

Haberland, H., \& Mey, J. (1997). Editorial: linguistics and pragmatics. Journal of Pragmatics, 1, 1-12. http://dx.doi.org/10.1016/0378-2166(77)90019-4

Harnish, R. M. (1991). Logical Form and Implicature. In S. Davis (Ed.), Pragmatics: A Reader. London: OUP.

Haverkate, H. (1983). Strategies in Linguistic Action. Journal of Pragmatics, 11, 637-656. http://dx.doi.org/10.1016/0378-2166(83)90088-7

Holmes, J. (1995). Women, Men and Politeness. Singapore: Longman Singapore Publishers Ltd.

Kadman, N. (2001). Formal Pragmatics: Semantics, Pragmatics, Presupposition, and Focus. Malden: Blackwell Publishers.

Kasper, A. (Ed.). (1995). Pragmatics: Critical Concepts (pp. 1-5). London \& New York: Routledge.

Kasper, G., \& Kellerman, E. (Eds.). (1997). Communication Strategies: Psycholinguistics and Sociolinguistics Perspective. London: Longman.

Langrehr, D. (2001). Advertising and Cognition. Retrieved from http://garnet.acns.fsu.edu.2001

Leech, G. N. (1966). English in advertising. London: Longman.

Leech, G. N. (1983). Principles of Pragmatics. London: Longman.

Levinson, S. (1983). Pragmatics. Cambridge: Cambridge University Press.

Levinson, S. C. (1979). Activity types and language. Linguistics, 17, 365-399. http://dx.doi.org/10.1515/ling.1979.17.5-6.365

Levinson, S. C. (2000). Presumptive Meanings: The Generalized Conversational Implicatures. Cambridge, Massachusetts \& London: The MIT Press.

Mcquiddy, I. W. (1986). Some conventional aspects of indirectness in conversation. Ph.D. Diss. University of Texas.

Pilegaard, M. (1997). Politeness in written business discourse: A text linguistic perspective on requests. Journal of Pragmatics, 8, 223-224. http://dx.doi.org/10.1016/S0378-2166(96)00084-7

Pratt, M. L. (1997). Toward a speech act theory of literary discourse. Bloomington: Indiana University Press.

Rudako, J. (2001). Case Studies in Linguistic Pragmatics. Lanham, Maryland: University Press of America.

Schiffrin, D. (1994). Approaches to discourse. Oxford: Basil Blackwell.

Searle, J. (1976). The classification of illocutionary acts. Language in Society, 5(1), 1-24. 
http://dx.doi.org/10.1017/S0047404500006837

Searle, J. (1979). Expression and Meaning. Cambridge: Cambridge University Press. http://dx.doi.org/10.1017/CBO9780511609213

Searle, J. (1995). Indirect speech acts. In P. Cole \& J. L. Morgan (Eds.), Syntax and Semantics 3: Speech Acts. New York: Academic Press.

Segal, E. (1993). Man, Woman and Child. New York: Random House.

Simpson, P. (1997). Language through Literature: An introduction. London and New York: Routledge. http://dx.doi.org/10.4324/9780203279175

Slembrouck, S. (1998-2000). The principle and its attendant maxims. Retrieved from http://bank.rug.ac.be/da/pp.htm

Thomas, J. (1995). Meaning in Interaction: An Introduction to Pragmatics. New York: Longman Group Limited.

Traugott, E. C., \& Pratt, M. L. (1980). Linguistics for Students of Literature. New York: Harcourt Brace Javanovich, Inc.

van Dijk, T. A., \& Kintsch, W. (1983.). Strategies of Discourse Comprehension. New York: Academic Press, Inc.

Yeung, L. N. T. (1997). Polite requests in English and Chinese business correspondence in Hong Kong. Journal of Pragmatics, 27, 505-522. http://dx.doi.org/10.1016/0378-2166(95)00050-X

Yule, G. (1996). Pragmatics. London: OUP.

\section{Notes}

Note 1. All Coca-Cola advertisements (1886-1980) are adopted from Courtland, L. Bovée and William F. Arens' Contemporary Advertisement (1982).

Note 2. Pragmatics can be applied to the explanation of novel, drama and other literary texts. See, Leech \& Short (1981), Attridge (1982), Bach \& Harnish (1979), Bennison (1993), Carter \& Burton (1996), de Beaugrande \& Dressler (1981), van Dijk (1976), Downes (1981) etc.

Note 3. The novel is adopted from Fan Jiacai (1998). Fan (1998) tries to prove that "choice of linguistic forms" is rhetoric. However, the example is analyzed from a different perspective, i.e., the perspective of pragmatic strategies.

Note 4. Classified by target audience, there are two major kinds of advertisement: consumers and business. The former is aimed at individuals or ultimate consumers who buy products for personal or non-business reasons. Most television, radio, newspaper and magazine ads are consumer advertisements. The manufacturers of the product or the dealers who sell the product sponsor them. They are usually directed at the ultimate consumer of the product or at the person who will buy the product for someone else's use. Business advertisement is aimed at people in business who buys products for business use. There are four types of business advertisement; industrial, trade, professional, and agricultural.

\section{Copyrights}

Copyright for this article is retained by the author(s), with first publication rights granted to the journal.

This is an open-access article distributed under the terms and conditions of the Creative Commons Attribution license (http://creativeecommons.org/licenses/by/3.0/). 